\title{
DIGITALIZATION AS A NEW DIRECTION IN EDUCATION SPHERE
}

\author{
Rui Dinis Sousa ${ }^{1}$, Beybitkul Karimova ${ }^{2 *}$, Sergey Gorlov ${ }^{3}$ \\ ${ }^{1}$ University of Minho, 4800-058, Guimaraes, Portugal \\ ${ }^{2}$ Korkyt Ata Kyzylorda State University, 120014 Aiteke bi str. 29A, Kyzylorda, Kazakhstan \\ ${ }^{3}$ North-Caucasus Federal University, 1, Pushkin str., Stavropol, Russian Federation
}

\begin{abstract}
Digitalization in education sphere is the new paradigm of high technologies development. The article proves that digital technologies are relevant and widely used in various areas of society: management, economic relations, science and education. However, digitalization of the educational process is of particular importance, because the several factors such an advance of the quality and relevant experience in this sphere. Today, important transformation processes are taking place in the field of education: electronic textbooks, Internet portals, databases of information needs are spreading, systems of online courses and distance learning are actively developing.
\end{abstract}

\section{Introduction}

The field of education is one of the most relevant today. Education is the significant factor of the most productive sectors of economy. According to the programs on grant financing and prospects for further economic development, an educated nation is the guarantor of a highly developed state. Digital technologies are used today in almost all sectors of the economy, education is a priority. An important point that creates competitive advantages for universities is the integration of science and education. According to the last decade education sphere cardinally had changed. A smart education system involves providing access to content around the world, building learning in an interactive environment. It has been established that the digitalization of education identifies risks and problems that require solutions. Education processes as the aspect of the digitalized technologies - are the specific new sphere for promoting and developing the economy of the Republic, in achieving high results of improvement and attracting investment from the outside. Kazakhstan is the new economic approach of a breakthrough, gradually begin to introduce innovations in every sector of the economy, adopted various strategies and programs for the development and application of innovation, and especially in the tourism industry. Today, Kazakhstan is the new economic approach of a breakthrough, gradually begin to introduce innovations in every sector of the economy, adopted various strategies and programs for the development and application of innovation. The country should carry out accelerated technological modernization through the cultivation and introduction of new industries, the development

\footnotetext{
*Corresponding author: karimovab72@mail.ru
} 
of industrial infrastructure. In the Message of this year "New opportunities for development in the conditions of the Fourth Industrial Revolution" one of the tasks defined is the development of human capital, providing for the creation of its own advanced educational system. To do this, we need to adapt the field of education to the needs of innovation industrialization, aimed at the transition from the practice of knowledge transfer to the formation of creative thinking skills, the ability to find the necessary information and correctly apply it. Education is the new priority, which contributes to improving the competitiveness of national economies in the context of increasing globalization. Nowadays, there are many approaches, which will influence on the trends in the education sphere. Digitalization means that there are will be special technics in the education management and it will be the central factor in the growth of production and labor productivity. As the world becomes increasingly digital, digital platforms become an important tool for increasing the efficiency of the digital ecosystem; help establish high-speed and reliable communications, support the process of joint creation of products and services by organizations from different countries and time zones [1].

According for the government program "Digital Kazakhstan": «In higher education, the requirements for the quality of training in educational institutions will be increased». [2]. Digital Technology Practices affect not only equipment innovations learning process, but also modernizing research activity. The most important thing is that the key higher educational institutions appeared not only understand mania, but also the actual digital transformation [3].

Digital technologies in education sphere means that there are will be the new approach in artificial intelligence, that's why AI is a mathematical code based on certain algorithms which are influencing on people mind. The main examples of AI in education sphere are special platforms that are giving more easiest way of using and getting the new knowledge especially as we know that in development countries the role of teacher plays the robot, for example In several states of US. However, in the near future, AI will be able to independently change existing codes and even create new ones. This development is already in its nascent stages as part of the so-called Industry 4.0 and the Internet of Things (IoT). Such technologies allow physical objects to interact with each other, eliminating the need for human participation. Thanks to certain algorithms and neural-like computing structures, and the use of big data and the Internet, modern computers already have predictive and self-learning functions.

\section{Literature review}

The study of the theory and practice of digitalization in education is based on the works of Sue Myburgh, Anna Maria Tammaro, R.S. Heller, Pérez-Sanagustín, M. Nussbaum, C-C. Tsai, J. van Braak, Ronaldo Mota, David Scott, G. W. A. Dummer J. Mackenzie Robertson, Stuart Ferguson, Dr Konstantin Schamber. Issues of socio-economic effectiveness are highlighted in the works of Kazakhstan researchers Ziyadin S.T., Doszhan R.D., they wrote that Kazakhstan's content- an indicator of the level of technological and industrial-innovative development of Kazakhstan, which is a share of the value of Kazakh goods, services and labor. [4] In this connection, there is a contradiction: on the one hand, a large number of digitalization in education processes are held annually in the Republic of Kazakhstan, including the world level, but the effectiveness of these measures is not assessed in view of the lack of a methodological basis. Other Kazakhstan researchers Sayabek, Z., Ainur, M., Ulan, T., Gulvira, A., Aizhan, K., \& Zhanar, T. wrote in their work that the main result in teaching process the exact role of leadership practices in the development of expertise in teaching and in what manner the expert. The next point of view were on these Kazakhstan researchers - S.T. Ziyadin, B. Zh. Ermekbayeva and others mentioned in their work that the digital economy generates new effects associated with the transformation of economic 
relations, which is of an informational nature, so according of that there is will be the specific circumstances for education implementation development [2].

Sue Myburgh, Anna Maria Tammaro finally suggest a model that could be used internationally to educate librarians for their new roles and social responsibilities in a digitized, networked world. M. Nussbaum, C-C. Tsai, J. van Braak mentioned in their work the next that computers \& Education aims to increase knowledge and understanding of ways in which digital technology can enhance education, through the publication of high quality research, which extends theory and practice. R.S. Heller argued in his work discusses the evaluation of instructional computer software. Groups who evaluate software are described, including EPIE (Educational Products Information Exchange); the evaluation process is discussed, including formal and informal software reviews; criteria for software evaluation are considered; and the importance of participation in the review process by the education community is emphasized. Ronaldo Mota, David Scott mentioned that by combining the theoretical and the practical, our aim is to explain how and under what conditions new modes of learning can be put into practice successfully and sustainably, in order for the learner to develop innovatory skills and dispositions for work and in the life course. The use of digital platforms in the so-called "digital factories" is revolutionizing the ways of technology commercialization. Trading platforms based on digital platforms transform not only the market of services, but also scientific and technical activities $[5,6,7]$.

G. W. A. Dummer J. Mackenzie Robertson wrote that specific equipment is so necessary to improve the quality in education sphere, educational Electronics Equipment 1967-68 presents a critical review of electronic and electronic-based equipment designed precisely for educational and instructional purposes [8].

Stuart Ferguson wrote that aimed at practitioners and students alike, this publication covers specific types of library and information agencies, discusses specific aspects of library and information management and places developments in library and information services in a number of broad contexts: socio-economic, ethico-legal, historical and educational, because libraries is the main place of getting knowledge as professor staff and as students [9].

Dr Konstantin Schamber wrote that scientific research is making progress in this area, and projects involving nanorobots will soon be implemented [10].

In this connection, there is an increasing need for the development of a network platform covering the components, tools for implementing the research projects developed in practice, and the directions for their practical use.

\section{Theoretical framework}

\subsection{Digitalization in education sphere}

In the context of globalization of modern of the scientific world, we undoubtedly must speak on the establishment and testing of expert activities centers of digitalization together with regional and Kazakhstan companies [11]. Attention must be directed to the development of processing and testing of teaching and learning complexes, training simulators, and simulators, virtual laboratories for in-depth teachings of mathematics, computer science, financial mathematics and digital economics. The development of digital higher education reference must be accompanied monitoring the needs of the modern production market, the introduction and the digitalization of educational programs of all levels in accordance with the requirements for key- digitalization competences for each level of education, ensuring their continuity. Speaking of digitalization of higher education institutions, we mean not only IT universities. Digitalization should fundamentally touch all universities: economic, legal, natural, scientific $[12,13]$. 
Undoubtedly, the intellectual nation plays a special role not only for the President of the Republic of Kazakhstan, but also of the state as a whole, therefore education occupies an important place. In this regard, a number of educational programs were adopted; innovative technologies are gradually being introduced into schools and universities of the republic. The important role is playing by qualified training [14].

Actually new technologies in digitalization area changes another sectors too. The primary objectives are to guarantee the production of sufficient food and to ensure a fair standard of living for people engaged in agriculture sector. For example, this technology helps us to use new products more effectively than on previous time.

Mobile solutions. The most notable technological trend in today's education industry is the emergence of solutions for mobile devices. Mobile solutions have changed the approach to "provisioning". Unwavering, it would seem, the position where we can take online courses, cramps the digital format of receipts on the screens of smartphones and tablets. The advantages of this format are many: useful technology, economy of time, and, take the entity to the best libraries in the world.

The most popular web sites that are using in universities are coursera.org, MOOC courses, online education system. All of it are helping to find out useful information and to learn easier than without it.

Speaking about the communication between the lecturer and the student, the most commonly used information is via e-mail. It is worth paying attention to such trends as the use of short text messaging (SMS) service using special Internet platforms, communication via Internet messengers, as well as communication through social networks. With the help of SMS there is always an opportunity to inform participants about changes in the plan, to remind about the conference or an important program $[15,16]$.

\section{Data descriptions and analysis}

\subsection{The Kazakhstan education sphere: An overview (digital aspect)}

In the structure of the economy of Kazakhstan is increasing every year the share of the mining industry, leading to it so ne-sided development and reduce the overall competitiveness of Kazakhstan's economy. However, the mining industry would be a consumer of the products and services of enterprises belonging to other sectors of the economy and, thus, contribute to macroeconomic stability, economic modernization and social well-being of the people of Kazakhstan. Kazakhstan's content- an indicator of the level of technological and industrialinnovative development of Kazakhstan, which is a share of the value of Kazakh goods, services and labor used in the implementation of the enterprise in the territory of the Republic of Kazakhstan. The description discusses the need for the development of local content in terms of innovative development of the national economy of Kazakhstan.

If we will analyze these factors of digital technologies in education sphere, we see that for the last 3-4 years the statistics of using computers is growing up. (Figure 1).

In the developed world, most of the innovation falls on University science, so it is necessary to continue to work on the development of research universities in Kazakhstan. Successful universities should be Autonomous, academically free and research-oriented. According to this, the state policy in the field of education and training of professional personnel should solve the following tasks:

- definition of training for innovation as one of the priorities for the development of education;

- establishment of institutions for the training, certification and retraining of workers and technicians with the participation of the state and the private sector; 
- improving the material,technical and methodological base of all types of education;

- development and implementation of educational standards that meet international requirements;

- international cooperation in the field of training and attracting highly qualified specialists to work in Kazakhstan on new production facilities, etc.;

- creation (on the basis of international experience) of new or conversion of existing higher education institutions into specialized institutes (universities) for training in the field of high-tech industries;

- training of specialists in the specialties necessary for the development of innovative activities in the country, such as: managers and experts of innovative projects; specialists in international marketing and patent law, assessment of the potential risk of innovative projects and ways to reduce it, the organization of venture financing, etc."

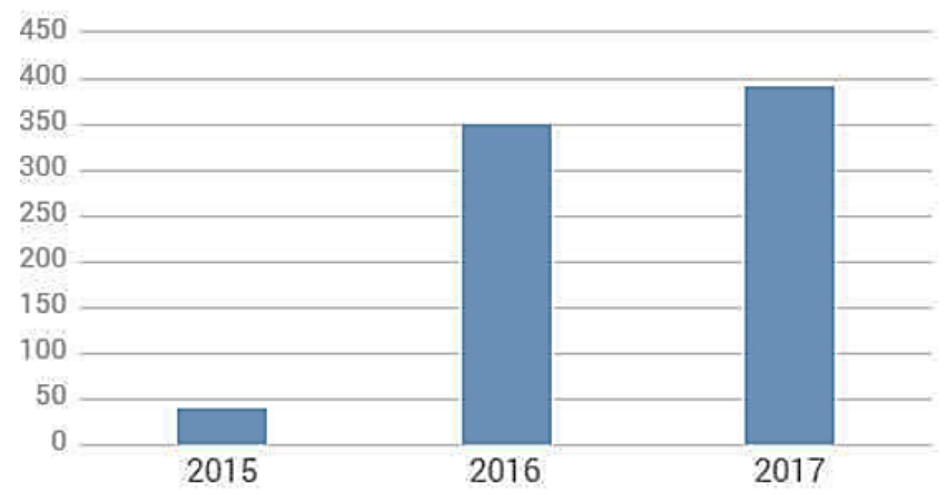

Fig. 1. The distribution of research costs in the most important areas of scientific and technical activities in education in Kazakhstan of [compiled by the author].

The most valuable knowledge today is creative thinking, the ability to process knowledge, to create new solutions, technologies and innovations. To do this, it is necessary to develop and implement new methods, new forms of teaching, to attract specialists with an innovative type of thinking and teaching.

\section{Methodology}

Education in digital conditions is a part of the region's economy. Depending on the region, special qualities of it can be the main source of income. Digital technologies has organized many jobs, improved regional infrastructure and the popularity of the region [5]. Like any branch of economic activity, the education industry requires constant development. Moreover, development is impossible without research. In order to choose the development of digitalized education sphere can attract more users and than to grow up the economy of the Republic of Kazakhstan.

With the help of social networks (Vkontakte, Odnoklassniki, Instagram, Facebook, My World, Twitter), $62.4 \%$ of those surveyed learn about diversifications, festivals, cultural diversifications, etc. Moreover, $27.7 \%$ of the surveyed learn about diversifications, festivals, cultural diversifications, etc. from the media (TV, Radio, Magazines, Republic newspapers, and another source).

The direction studied is interesting for residents and guests of the country and requires improvement. [11] 
According of this the main direction of promoting this industry depends on economic and financial models. The risk, which contribute this position, described in the next analysis. The considered models will be reduced to the following mathematical formulations:

1. Model of financial function:

$$
\begin{gathered}
S=B C\left(\frac{i}{m} ; n * m ; 0 ;-P\right), \quad \text { with restrictions: } \\
P=-P C\left(\frac{i}{m} ; n * m ; 0 ; S\right)(1)
\end{gathered}
$$

where: returns the future value of the contribution $\mathrm{S}$ based on compound interest with annual interest rate $\mathrm{i}$, if the contribution $\mathrm{P}$ is $\mathrm{n}$ years, and interest is calculated $\mathrm{m}$ times in year. Here $\mathrm{P}$ - the number of funds invested in the bank, it is entered with the sign

$i=(n * m ; 0 ;-P ; S) \mathrm{m} \quad-$ the average expected income for the $\mathrm{j}$-th investment project;

\section{i-Annual interest rate}

Returns the annual interest rate under which the initial amount $\mathrm{P}$ is to be put, so that after $\mathrm{n}$ years to get the total amount of deposit $\mathrm{S}$. Here $\mathrm{P}$ is the amount of money invested in the bank, it is entered with a minus sign:

$$
n=O K R V V E R K(\operatorname{KEPER}(i / m ; 0 ;-P ; S) ; 1) / m
$$

All three items are being performed at each iteration of the optimization method algorithm, and thus, a dynamic adjustment of the optimization process can be made. At each step of the algorithm, income is calculated as a function of demand and costs are calculated from the magnitude of production and the investment.

It should been noted that the disadvantage of the presented models is that they do not take into account the risk dynamics, if we consider the investment projects being implemented and additional investments in them.

\section{Conclusion}

Leadership skills would been established already in school. Leadership is one of the categories which plays the main role on the forming the key aspect of the education processes in the whole economy. Digital technologies in the region will be successful due to: multipurpose sharing of production capacities, lower costs, due to the rational, as well as the concentration of distribution networks, formation of channels of information, knowledge, technology and managerial expertise. Use economy model of R\&D commercialization in practice can open up new opportunities for obtaining synergistic effect from its operation due to the optimal use of generalized resource, personnel, organizational, informational and other support within the framework of a unified strategy of innovative development of an economic entity, region and country as a whole. Strategies for the post-crisis development are offered taking into consideration the adequate management systems for risks, profitability, liquidity and capital. FpereDigitalization is significantly ahead of the existing system of production requirements for the composition of professions engaged in the labor market. The digital economy requires that people have digital skills to benefit from it. At the same time, the 
current level of computer (digital) literacy of the population is $76.2 \%$, and its growth is necessary in the coming years.

\section{References}

1. Ziyadin S., Ermekbaeva, B., Supugaliyeva G., Doszhan R. Transformation of Basic Indicators of Socio-Economic Processes in the Digital Economy // IBIMA Innovation Management and Education Excellence through Vision 2020, 2018

2. Sayabek, Z., Ainur, M., Ulan, T., Gulvira, A., Aizhan, K., \& Zhanar, T. Academy of Strategic Management Journal, 17(3), 1-13. (2018).

3. Heller, R. S. Evaluating software: A review of the options. Computers \& Education, 17(4), 285-91. (1991)

4. Myburgh, S., \& Tammaro, A. M. Exploring education for digital librarians: meaning, modes and models. Elsevier. (2013).

5. Pérez-Sanagustín, M., Nussbaum, M., Hilliger, I., Alario-Hoyos, C., Heller, R. S., Twining, P., \& Tsai, C. C. Research on ICT in K-12 schools e A review of experimental and survey-based studies in computers \& education 2011 to 2015. Computers and Education, 104, A1-A15. (2017).

6. Agency for statistics / / Available at: www. statgov.kz. - 2018.

7. Mota, R., \& Scott, D. Education for innovation and independent learning. Elsevier. (2014).

8. Dummer, G. W. A., \& Robertson, J. M. (Eds.). Fluidic Components and Equipment 1968-9: Pergamon Electronics Data Series. Elsevier.. (2013).

9. Ferguson, S. J. Libraries in the Twenty-First Century: Charting Directions in Information Services. Elsevier. (2007).

10. Schamber, K. Internationalisierungsprozesse in chinesischen Großunternehmen in der VR China: eine deskriptive Analyse von Expansionswegen und Personalpraktiken. Lang, Peter, Internationaler Verlag der Wissenschaften. (2011).

11. Ziyadin, S., Shash, N., Kenzhebekova, D., Yessenova, G., \& Tlemissov, U. Data on the role of leadership in developing expertise in teaching in developing country. Data in brief, 18, 1127-1133. (2018).

12. Ziyadin, S., Suieubayeva, S., Utegenova, A. Digital Transformation in Business //Lecture Notes in Networks and Systems 84. P. 408-415 (2020)

13. Ziyadin, S., Serikbek, A. Lecture Notes in Networks and Systems 84, P. 290-297 (2020) DOI: $10.1007 / 978-3-030-27015-5 \_35$

14. Ziyadin, S., Arzayeva, M., Mediyeva, G., Mustafina, A.\&Tlemissov, U. 30th IBIMA Conference: Madrid, Spain, 8-9 November, pp. 4152-4161 (8) (2017)

15. Akhmetshin, E. M., Larionova, G. N., Lukiyanchina, E. V., Savitskaya, Y. P., Aleshko, R. A., \& Aleynikova, O. S. Journal of Entrepreneurship Education, 22 (2019).

16. Akhmetshin, E. M., Mueller, J. E., Yumashev, A. V., Kozachek, A. V., Prikhodko, A. N., \& Safonova, E. E. Journal of Entrepreneurship Education, 22(1) (2019). 